\title{
PERTARUNGAN KUASA DALAM WACANA ISLAM NUSANTARA
}

\author{
Ahmad Khoirul Fata \\ Institut Agama Islam Negeri Sultan Amai Gorontalo, Indonesia \\ E-mail: cakfata@gmail.com \\ Moh. Nor Ichwan \\ Universitas Islam Negeri Walisongo Semarang, Indonesia \\ E-mail: ichwanzr@yahoo.co.id
}

\begin{abstract}
This article examines power struggle in the discourse of Islam Nusantara which becomes very popular in contemporary Indonesian Islam. The idea of Islam Nusantara is not different from Islam in general, but with distinctive charactericstics, such as tawâzun, itidâl, and tawassut. The proponents of this idea claim that their intellectual framework is based on the principle of maslahah mursalah, istib̧sân, and 'urf. Using critical discourse analysis, this article attempts to see the other side of Islam Nusantara discourse. This study is based on an assumption that language and discourse are not only an instrument to convey ideas, but also a means to construct social reality. Social activities are always related to and constructed by their social settings. This article argues that the discourse of Islam Nusantara emerges as a part of struggle for influence between mainstream Islamic movements, such as Nahdlatul Ulama and Muhammadiyah, and new transnational Islamic movements, such as Tarbiyah, Hizbut Tahrir, and Salafis. The use of the term Islam Nusantara is indeed the effort of mainstream Islamic movements to create the image of indigenous Islamic movements, different from the newly imported Islamic movements. However, the discourse of Islam Nusantara seems to be reductionist and monolithic in perceiving diverse realities of Islam in Nusantara.
\end{abstract}

Keywords: Islam Nusantara; mainstream Islamic movements; transnational Islamic movements.

\section{Pendahuluan}

Islam Nusantara menjadi gemuruh wacana dalam dinamika Islam di Indonesia kontemporer. Wacana ini muncul dalam ruang historis 
Indonesia yang semakin dinamis pasca-tumbangnya kekuasaan Orde Baru dengan lahirnya berbagai gerakan Islam, mulai dari yang kanan, kiri, radikal hingga liberal.

Era kebebasan yang dibuka semenjak Presiden BJ Habibie mendorong kemunculan gerakan-gerakan Islam dengan ragam warna. Gagasan-gagasan yang disajikan pun berdesak-desakan di ruang publik untuk merebut perhatian masyarakat Muslim Indonesia. Ruang publik pun menjadi "pasar bebas" yang memberikan berbagai tawaran menarik bagi para konsumennya. Kontestasi terbuka seringkali terjadi dengan perdebatan yang sengit dan pro-kontra selalu mengiringi.

Sebagai wacana baru yang turut meramaikan diskursus keislaman di Indonesia, Islam Nusantara menjadi tema menarik yang segera mencapai popularitasnya setelah organisasi Islam terbesar-Nahdlatul Ulama (NU)-menjadikannya sebagai tema muktamar di Jombang 1-5 Agustus 2015 lalu. Perdebatan pun segera mewarnai ruang publik, dan semakin sengit saat $\mathrm{NU}$ sendiri belum merumuskan rupa dan bentuknya.

Artikel ini melihat sisi lain wacana Islam Nusantara yang belum terungkap ke permukaan. Dengan menggunakan analisis wacana kritis tulisan ini dibangun atas asumsi bahwa bahasa dan wacana bukan sekadar alat untuk menyampaikan ide dan gagasan dalam sebuah komunikasi. Lebih dari itu ia merupakan alat untuk mengonstruksi realitas sosial, dan merupakan aktivitas sosial yang selalu terikat dengan dan dikonstruksi oleh setting sosialnya. Kenyataan seperti ini membuat banyak pihak berupaya menjadikan bahasa dan wacana sebagai alat untuk membangun realitas sosial sesuai dengan keinginannya, sehingga seringkali terkandung varian kuasa tertentu yang beredar di ruang publik.

\section{Konsep Islam Nusantara}

Bagi sebagian kalangan terminologi Islam Nusantara merupakan sebuah kekeliruan karena mereduksi Islam dalam batasan lokalitas ruang-waktu. Islam bagi mereka merupakan agama yang tunggaluniversal melampaui batasan-batasan ruang waktu, sehingga tidak tepat jika Islam diberi label-label tertentu.

Kritik tersebut dianggap Azyumardi Azra sebagai pandangan idealistik tentang Islam yang tidak memperhatikan realitas historisempiris perjalanan Islam sepanjang sejarah dengan keragaman realitas sosial, politik, budaya di wilayah yang berbeda. Azra menilai Islam tunggal dalam kerangka idealistik itu hanya ada pada level al-Qur'ân 
(dan hadîth), yang membutuhkan penjelasan dan rincian agar bisa dilaksanakan seluruh umat Islam. Pada level ini muncul perbedaan penafsiran yang melahirkan mazhab dan aliran beragam. ${ }^{1}$ Menurutnya, sesungguhnya Islam Nusantara tidak berbeda dengan Islam di belahan dunia lain yang mengakui Rukun Iman dan Rukun Islam yang sama. Namun Islam Nusantara tampak berbunga-bunga dalam mempraktikkan ajaran Islam (flowery Islam), sehingga menjadi unik dan berbeda dengan praktik Islam di negara-negara lain. ${ }^{2}$

Meski berbunga-bunga, Afifuddin Muhajir meyakini ekspresi keislaman di Nusantara hanya bergerak di ruang tertentu yang masih ditoleransi sharî'ah. Dijelaskan Muhajir, al-Qur'ân sebagai sumber utama ajaran Islam mengandungi tiga hukum; aḅkâm i'tiqâdîyah, ạ̣kâm khuluqîyah, dan aḅkâm 'amalîyah. Hukum yang pertama dan kedua aḅkâm i'tiqâdìyah dan khuluqîyah) bersifat konstan dan universal karena keduanya menyangkut hal-hal yang esensi dalam Islam ('aqîdah) dan yang dapat diterima oleh seluruh umat manusia (akblâq). Namun tidak demikian dengan yang ketiga. Selain mengandungi hukum-hukum yang tetap (qat'îyat/thawâbit), ạ̣kâm 'amalîyah juga memiliki hukumhukum yang bersifat dinamis dan berubah-ubah seiring dengan keberadaan maslahah dalam ruang dan waktu tertentu (ijtihâdîyah). Muhajir memandang posisi Islam Nusantara berada pada ruang aḅkâm 'amalîyah ijtihâdîyah, sehingga menjadi absah jika meletakkan kata "Nusantara" di belakang kata "Islam" untuk memberi sifat tertentu pada kata yang pertama. ${ }^{3}$

Karena bergerak di wilayah ijtibâdiyah itulah Abdul Moqsith Ghazali menegaskan bahwa keberadaan Islam Nusantara itu tidak untuk mengubah doktrin agama Islam, namun justru untuk mengaplikasikan ajaran-ajaran Islam dalam konteks keindonesiaan. Dengan meminjam teori Abû Ishâq al-Shâțibî, Ghazali menjelaskan, Islam Nusantara berupaya untuk melakukan ijtihâd tatbîq $\hat{\imath}$ yang berfokus pada aspek penerapan hukum, bukan untuk menciptakan

\footnotetext{
1 Azyumardi Azra, "Jaringan Ulama Nusantara", dalam Akhmad Sahal dan Munawir Aziz (eds.), Islam Nusantara: Dari Ushul Fiqh hingga Paham Kebangsaan (Bandung: Mizan, 2015), 171-172.

2 Ibid., 170-171.

3 Afifuddin Muhajir, "Meneguhkan Islam Nusantara untuk Peradaban Indonesia dan Dunia”, dalam Sahal dan Aziz (eds.), Islam Nusantara, 61-62.
} 
hukum baru (ijtihâd istinbâtî̀). ${ }^{4}$ Agar ajaran-ajaran Islam bisa diresapi dengan baik dan kemaslahatannya juga dirasakan oleh masyarakat yang mendiami wilayah Nusantara dengan karakternya yang khas itu. Jelas Ghazali, Islam Nusantara menggunakan metodologi maslahahmursalah, istiḩân, dan 'urf dalam proses ijtihadnya. ${ }^{5}$

Maslahah-mursalah menjadi pilihan karena dianggap sesuai dengan tujuan hukum Islam (haythum kânat al-maslahah fathamm shar' Allah wa haythum kânâ shar' Allah fathamm al-maslaḥah). Dalam konteks Islam di Indonesia, Ghazali menegaskan, metode seperti ini pernah digunakan para ulama untuk menerima Pancasila sebagai dasar negara Indonesia yang final, karena dianggap tidak bertentangan dengan al-Qur'ân dan hadîth, serta menjadi payung bagi semua golongan dan etnis yang berbeda sehingga bisa menghindarkan bangsa ini dari bahaya disintegrasi. ${ }^{6}$

Istihsân-yang didefinisikan oleh ulama Mâlikîyah sebagai upaya meninggalkan hukum umum (buk.m kulli) dan mengambil hukum pengecualian (bukkm juz'?), meninggalkan analogi yang terang (qiyâs jalì) dan mengambil analogi yang samar (qiyâs khafî̀) - menurut Ghazali digunakan sebagai salah satu metodologi dalam praktik keberislaman di Nusantara mengingat dalil "apa yang dipandang baik oleh kebanyakan manusia, maka itu juga baik menurut Allah". Salah satu contoh aplikasi metode ini di Nusantara, menurut Ghazali, adalah cara berpakaian Muslimah di Nusantara yang memakai kain sampir, baju kebaya, dan kerudung penutup kepala serta membiarkan tapak kaki dan bagian bawah betisnya kelihatan. Meski sharî‘ah menetapkan kewajiban menutup aurat bagi perempuan, namun hal itu dianggap Ghazali sebagai kebolehan karena merupakan istibsân bi al-urf (mengambil hal baik dengan berdasarkan pada tradisi masyarakat). ${ }^{7}$

Menurut Ghazali, al-urf atau tradisi yang berlaku di masyarakat digunakan metode ijtihad ulama Nusantara karena Islam sangat menghargai ragam kreasi kebudayaan masyarakat, selama tradisi itu tidak melanggar prinsip-prinsip kemanusiaan. Kaidah yang sering dipakai adalah al-âdah mubakkamah (adat bisa dijadikan sebagai hukum) dan al-thâbit bi al-urf ka al-thâbit bi al-naṣs (sesuatu yang telah

\footnotetext{
4 Abdul Moqsith Ghazali, "Metodologi Islam Nusantara", dalam Sahal dan Aziz (eds.), Islam Nusantara, 106.

${ }^{5}$ Ibid., 107.

${ }^{6}$ Ibid., 107-109.

${ }^{7}$ Ibid., 110-112.
} 
tetap menurut adat itu seperti sesuatu yang tetap menurut nas). Al-urf menjadi pegangan ulama Nusantara, karena mereka ingin masyarakat bisa berislam tanpa harus tercerabut dari akar budayanya sendiri. Praktik konkret dari metode ini terjadi pada budaya wayang kulit, masjid Kudus yang menyerupai candi Hindu-Buddha, serta konsep gono-gini dalam pembagian waris. ${ }^{8}$

Metodologi itu diyakini telah memberikan warna khas dan unik dalam ekspresi keislaman di Nusantara, yang berbeda dengan Islam di Timur Tengah (Arab). Karakter khas Islam di Nusantara menurut Said Aqil Siroj adalah tawẫun, i'tidâl, tawașsut, serta selalu berupaya mencari konvergensi dan titik temu di antara berbagai mazhab pemikiran dan aliran keagamaan. ${ }^{9}$ Selain faktor itu, keunikan Islam di Nusantara juga diyakini terbentuk oleh kondisi geografis kepulauan di wilayah Nusantara, sehingga melahirkan masyarakat kosmopolit dengan sikap toleran-terbuka terhadap etnik-budaya lain. ${ }^{10}$

Dengan karakter khas itu, Islam di Nusantara membentuk sebuah ranah budaya (Islamic cultural spheres) tersendiri dalam dunia Islam. Azra menyebutkan setidaknya ada delapan wajah peradaban di dunia Islam, yaitu: Persia-Iran, Turki, anak benua India, Nusantara, Cina atau Asia Timur, Afrika Sudan/Afrika Hitam/Sub-Sahara, dan belahan dunia Barat. Identitas Islam di Nusantara disatukan oleh beberapa hal, yaitu: tradisi keulamaan/keilmuan yang sama; Bahasa Melayu sebagai lingua franca; dan kesamaan di bidang sosial-budaya. Contoh kesamaan tersebut, pada bidang teologi menganut Ash'ârîyah, fiqh menganut Shâfi îyah, dan tasawuf mengikuti al-Ghazâlî. ${ }^{11}$

Meski unik dan khas, ortodoksi Islam di Nusantara tetap terjaga karena memiliki hubungan (sanad) dengan tradisi Islam di belahan dunia lain, terutama Timur Tengah (Arab). Hubungan itu telah terbentuk sejak abad ke $17 \mathrm{M}$ saat para ulama Nusantara kembali dari Makkah dan Madinah. ${ }^{12}$ Siroj menilai ulama Nusantara yang

\footnotetext{
8 Ibid., 112-115.

9 Said Aqil Siroj, "Rekonstruksi Aswaja Sebagai Etika Sosial," dalam Sahal dan Aziz (eds.), Islam Nusantara, 148-149

10 Muhammad Sulthon Fatoni, "NU dan Islam Nusantara," dalam Sahal dan Aziz (eds.), Islam Nusantara, 235. Lihat juga Bilal Muhammad, "Islam Indonesia Beda Dengan Islam Timur Tengah,” dalam http://www.kiblat.net/2015/03/19 /azyumardi-azra-islam-indonesia-beda-dengan-islam-arab/ (diakses 25 Februari 2016).

11 Azra, "Jaringan Ulama”, dalam Sahal dan Aziz (eds.), Islam Nusantara, 172.

12 Ibid.
} 
memberikan kontribusi bagi jalinan mata rantai tersebut adalah Shaykh Ahmad Khatib Sambas (1803-1875) yang berhasil memadukan Tarekat Qâdirîyah dan Tarekat Naqshabandîyah menjadi Tarekat Qâdirîyah wa Naqshabandîyah (TQN), kemudian dilanjutkan Shaykh Nawawi Banten (1813-1897), Shaykh Mahfudz Termas (w. 1919), Kiai Kholil Bangkalan (1819-1925), Shaykh Ihsan Muhammad Dahlan (1901-1952), hingga ke para pendiri Nahdlatul Ulama (NU). ${ }^{13}$

Dengan demikian, sesungguhnya secara substansial Islam di Nusantara tidak jauh beda dengan praktik keislaman di wilayahwilayah lain di belahan dunia Islam (Sunnî). Bahkan bisa disebut lebih dominan persamaannya dibanding perbedaan yang ada, mengingat aspek 'amalîyah ijtibâdîyah yang dimasuki Islam Nusantara hanya sebagian kecil dalam anatomi ajaran Islam. Namun pertanyaan yang kemudian muncul adalah mengapa perbedaan kecil itu justru dipertajam dengan penggunaan konsep Islam Nusantara? Di titik inilah kajian tentang Islam Nusantara tidak bisa dilepaskan dari ruang waktu yang melingkupi.

Meski mengaku tidak berbeda jauh dengan ekspresi Islam di belahan dunia lain, kalangan penyokong wacana Islam Nusantara sering menekankan aspek keunikan wajah Islam di kawasan Nusantara, yaitu fleksibel dan moderat. Untuk menegaskan karakter unik itu seringkali mereka membandingkan dengan karakter Islam di belahan dunia lain, terutama di kawasan Timur Tengah, seperti yang disampaikan Azra ${ }^{14}$, Siroj ${ }^{15}$, atau Din Syamsuddin. ${ }^{16}$ Di antara yang membedakan itu menurut mereka adalah wajah Islam Nusantara yang moderat (memilih jalan tengah), inklusif, toleran, anti-kekerasan, dan mengakomodasi budaya lokal. Hal itu dibedakan secara diametral dengan Islam yang ada di Timur Tengah yang penuh dengan konflik dan kekerasan.

\footnotetext{
13 Siroj, "Rekonstruksi Aswaja", dalam Sahal dan Aziz (eds.), Islam Nusantara, 151153.

14 Bilal Muhammad, "Islam Indonesia Beda dengan Islam Timur Tengah," dalam http://www.kiblat.net/2015/03/19/azyumardi-azra-islam-indonesia-beda-denganislam-arab/ (diakses 25 Februari 2016).

15 Bahtiar Rifai, "Said Aqil Siradj: 'Islam Indonesia bukan Islam Arab', dalam m.detik.com/news/wawancara/2978479/said-aqil-siradj-islam-indonesia-bukanislam-arab (diakses 25 Februari 2016).

16 Bilal Ramadhan, "Din: 'Watak Islam di Indonesia Beda dengan di Timur Tengah'," dalam m.republika.co.id/berita/dunia-islam/islam-nusantara/15/11/05 /nxbsaz330-din-watak-islam-di-indonesia-beda-dengan-di-timur-tengah (diakses 25 Februari 2016).
} 


\section{Gerakan Islam Transnasional}

Namun sayang wajah Islam di Nusantara yang khas itu dianggap sebagian pihak telah mengalami pergeseran ke arah konservatisme (conservative turn), yang terjadi pasca-kejatuhan rezim Orde Baru 1998. Martin van Bruinessen menyebutkan beberapa indikasi conservative turn tersebut, yaitu terjadinya konflik antaragama di berbagai wilayah, adanya upaya melegalkan hukum sharî́ah dalam hukum positif Indonesia dengan tuntutan pengembalian Piagam Jakarta dalam konstitusi, munculnya perda-perda sharî́ah di berbagai daerah, dan munculnya gerakan-gerakan Islam baru yang bersifat lintas negara (transnasional), serta munculnya fatwa-fatwa yang dianggap kontroversial dari Majelis Ulama Indonesia (MUI). ${ }^{17}$

Meski demikian, Bruinessen melihat beberapa fenomena yang menjadi indikasi adanya conservative turn tersebut bersifat sementara, sekadar respons atas demam perubahan dan perkembangan politik yang demokratis dan terbuka di era reformasi. Namun tidak demikian dengan keberadaan gerakan Islam transnasional yang banyak muncul dengan gerakannya yang dinamis. ${ }^{18}$

Menurut Masdar Hilmy, istilah gerakan Islam transnasional di Indonesia kemungkinan pertama kali digunakan oleh Syafii Maarif atau A. Hasyim Muzadi untuk menyebut kelompok Islamis yang membawa misi transformasi sosial-keagamaan secara radikal yang bersifat melintasi batas-batas nasionalisme keindonesiaan. ${ }^{19}$ Gerakan itu dinilai Hilmy telah melakukan transmutasi teologis-ideologis terhadap doktrin-doktrin keagamaan secara verbatim dan bulat-bulat dari sumber asalnya ke konteks Indonesia tanpa dibarengi dengan upaya kontekstualisasi doktrin secara signifikan, dan lebih mengedepankan proses arabisasi, ketimbang indonesianisasi Islam. ${ }^{20}$

Dengan meminjam kerangka teoretik Peter G. Mandaville, konsep Islam transnasional menurut Hilmy mencakup tiga hal: 1) pergerakan demografis, dengan terjadinya mobilitas yang dilakukan oleh orang perorang dan atau kelompok dari satu negara ke negara lainnya; 2)

17 Martin van Bruinessen, "Perkembangan Kontemporer Islam Indonesia dan 'Conservative 'Turn' Awal Abad Ke-21", dalam Martin van Bruinessen (ed.), Conservative Turn: Islam Indonesia dalam Ancaman Fundamentalisme (Bandung: Mizan, 2014), 24-30.

18 Ibid., 26-27 .

19 Masdar Hilmy, "Akar-akar Transnasionalisme Islam Hizbut Tahrir Indonesia (HTI)," dalam Islamica: Jurnal Studi Keislaman, Vol. 6, No. 1 (September 2011), 3.

${ }^{20}$ Ibid., 3. 
lembaga keagamaan transnasional, yang menyediakan jejaring antarlembaga keagamaan di sejumlah tempat atau negara; dan 3) perpindahan gagasan atau ide, yang melihat modus pergerakan atau perpindahan gagasan dari individu atau sekelompok individu di sebuah tempat atau negara ke individu atau sekelompok individu di negara lain. Dan ketiga hal itu terjadi seiring dengan globalisasi dan perkembangan teknologi informasi. ${ }^{21}$

Mengutip tesis Edward W. Said, Hilmy menjelaskan empat tahapan yang dilalui ketika sebuah gagasan mengalami perpindahan dari satu tempat ke tempat lain: pertama adalah a point of origin atau lokasi asal di mana seperangkat gagasan tercetus, dielaborasi, dan dikontestasikan dalam ruang wacana di tempat asal; kedua tahap distance transversed yang terjadi saat sebuah ide mengalami perjalanan dari satu tempat ke ruang dan waktu yang berbeda; ketiga tahap encounter stage yang terjadi ketika gagasan tersebut bertemu dengan gagasan atau ideologi lain serta dikontestasikan dalam sebuah ruang wacana yang bisa berujung pada sikap penerimaan, penolakan, modifikasi, dan adaptasi; dan yang keempat adalah tahap "transformasi" di mana gagasan tersebut menjelma menjadi sebuah entitas baru yang diterima oleh pihak penerima. ${ }^{22}$

Menurut Syarifuddin Jurdi proses transmisi gerakan Islam transnasional tersebut sesungguhnya telah terjadi sejak dahulu kala melalui jaringan ulama yang terbentuk pada abad ke 17-18 M. Jaringan itulah yang kemudian memberikan inspirasi pada organisasi-organisasi Islam di Indonesia seperti Sarekat Islam (SI)/Sarekat Dagang Islam, Jamiat Khair, al-Irsyad, Muhammadiyah, Nahdlatul Ulama (NU), Persatuan Islam dan lain-lainnya. ${ }^{23}$

Sementara gerakan-gerakan Islam baru seperti Gerakan Tarbiyah dan Hizbut Tahrir Indonesia mulai populer di beberapa kota besar di Indonesia pada dekade 1980-an, melalui, salah satunya, dengan maraknya penerjemahan buku-buku karya Yûsuf Qaraḍ̂âî, Hasan alBannâ, Sayyid Quṭb, Sấid Ḥawwâ, Muhammad al-Ghazâlî, Taqiy alDîn al-Nabhânî, dan Nâṣir al-Dîn al-Bânî. ${ }^{24}$

\footnotetext{
21 Ibid., 2.

22 Ibid., 4-7.

23 Syarifuddin Jurdi, "Pertautan Gerakan Wahdah Islamiyah dan Gerakan Transnasional," dalam al-Fikr: Jurnal Pemikiran Islam, Vol. 16, No. 3 (2012).

${ }^{24}$ Ibid.
} 
Kehadiran gerakan-gerakan baru itu turut melahirkan apa yang disebut oleh Yon Machmudi sebagai "santri baru", yang memiliki orientasi politik, ideologi keagamaan, dan sikap terhadap tradisi yang berbeda dari "santri lama". Kemunculan mereka bukan sekadar dipengaruhi oleh dinamika Islam lokal-nasional, namun lebih dari itu, ia sangat dipengaruhi oleh dinamika Islam internasional. Sebagian dari mereka tetap menjaga hubungan dengan gerakan-gerakan Islam mainstream (santri lama), sebagian lain menjaga jarak, dan sisanya menampakkan orientasi yang radikal. ${ }^{25}$

Di titik ini Machmudi pun membagi "santri baru" menjadi tiga varian: Konvergen, radikal, dan global. Varian pertama merujuk pada "santri baru" yang tetap menggabungkan dirinya pada gerakangerakan Islam mainstream lama, baik yang tradisionalis maupun yang modernis. Sementara varian kedua merupakan "santri baru" yang memiliki pandangan kurang positif (pesimis) terhadap langkah gerak perjuangan gerakan Islam mainstream dan cenderung menginginkan perubahan yang radikal di Indonesia. Sedangkan "santri global" adalah mereka yang lebih terpengaruh oleh gerakan-gerakan Islam transnasional di Timur Tengah, meskipun mereka sebetulnya berasal dari bagian gerakan Islam mainstream. ${ }^{26}$

Santri kovergen muncul di era 1970-an sebagai konvergensi dari kelompok tradisionalis dan modernis yang cenderung memperkaya khazanah keislaman mereka dengan kepustakaan yang berasal dari luar negeri, baik dari Barat atau Timur Tengah. Secara khusus dari kalangan modernis memiliki dua orientasi: gerakan pembaruan dan gerakan dakwah. Mereka memiliki kecenderungan sikap kritis terhadap kesarjanaan Islam klasik dan kesarjanaan arus utama, serta isu-isu dunia Islam global. Namun mereka cenderung menyetujui praktik yang dilakukan gerakan Islam tradisionalis dan modernis, serta sangat mendukung terhadap demokrasi. ${ }^{27}$

Sementara santri radikal merupakan kelompok-kelompok Islam yang meyakini signifikansi penggunaan paksaan dan kekerasan dalam perubahan sosial dan negara. Machmudi tidak memasukkan kelompok-kelompok yang menghendaki perubahan masyarakat dan

\footnotetext{
${ }^{25}$ Lihat Yon Machmudi, "Islamising Indonesia: The Rise of Jemaah Tarbiyah and the Prosperious Justice Party (PKS)" (Disertasi--Australian National University, 2006), 21.

${ }^{26}$ Ibid.

${ }^{27}$ Ibid., 31.
} 
politik melalui jalur konstitusional dalam terminologi ini. ${ }^{28}$ Pun demikian kelompok-kelompok Islam yang dikenal sering melakukan aksi kekerasan semacam FPI atau Laskar Jihad tidak termasuk kelompok santri radikal, karena meski mereka melakukan aksinya dengan kekerasan, namun mereka tidak memiliki orientasi mengubah sistem politik secara radikal. ${ }^{29}$

Santri varian ini mulai tampak di era 1980-an akibat dari sikap opresif rezim Soeharto terhadap kekuatan politik Islam serta orientasi kebijakan rezim yang sekular. Hal itu membuat sebagian kelompok Islam menjadi frustrasi dan terjadi proses radikalisasi dalam diri mereka. Gerakan model ini diwujudkan dalam organisasi Negara Islam Indonesia (NII), dan Jemaah Islamiyah (JI)..$^{30}$ Kelompok ini memiliki orientasi yang kuat pada al-salaf al-sâliḥ dan isu-isu dunia Islam global, tidak cocok dengan praktik yang dilakukan kelompok tradisionalis dan modernis, serta sangat menolak terhadap demokrasi. ${ }^{31}$

Berbeda dengan kecenderungan dua varian santri baru di atas, "santri global" tidak bisa mengidentifikasi dirinya pada kehidupan kelompok tradisionalis ataupun modernis. Anak-anak muda ini memiliki interes yang lebih besar pada isu-isu dunia Islam global dan gerakan transnasional, dengan sedikit ketertarikan pada isu-isu lokalnasional. Menurut Machmudi, ini merupakan bagian dari strategi mereka untuk menghindari sikap represif rezim Orde Baru. ${ }^{32}$

Dengan mengutip Azra, Machmudi menyatakan bahwa kelompok santri global ini dapat disebut juga sebagai gerakan neo-revivalisme. Pengguanaan kata "neo" untuk membedakan mereka dengan gerakan revivalisme di masa lalu, meski demikian mereka masih terkait dengan gerakan revivalisme lama itu. Neo-revivalisme dapat dikenali dari sikap kritis mereka terhadap institusi Barat, dengan perhatian lebih pada isu-isu internasional. ${ }^{33}$

Dalam konteks varian santri ketiga inilah, Bruinessen melihat setidaknya ada tiga jaringan utama kelompok baru tersebut, yaitu: Gerakan Tarbiyah; Hizbut Tahrir yang mengusung ide negara

\footnotetext{
${ }^{28}$ Ibid., 37.

${ }^{29}$ Ibid., 40.

${ }^{30}$ Ibid., 40-42.

${ }^{31}$ Ibid., 31.

32 Ibid., 42.

${ }^{33}$ Ibid.
} 
khilafah; serta gerakan Salafi. ${ }^{34}$ Selain ketiganya, Bruinessen juga melihat Ahmadiyah, Shî'iah, dan Jamaah Tabligh), sebagai bagian dari gerakan yang memiliki jaringan transnasional. ${ }^{35}$

Di antara gerakan-gerakan itu, Bruinessen menyebut Gerakan Tarbiyah sebagai gerakan Islam baru yang terpenting. Gerakan ini bermula dari kajian-kajian keagamaan dan berbagai pelatihan mental di masjid kampus. Saat reformasi 1998 kelompok ini mendirikan Kesatuan Aksi Mahasiswa Muslim Indonesia (KAMMI) dan menjadi salah satu unsur penting dalam proses reformasi. Selain itu mereka juga bergerak di ruang politik konstitusional melalui Partai Keadilan (PK), dan meraih suara yang signifikan setelah berubah menjadi Partai Keadilan Sejahtera (PKS). ${ }^{36}$

Menurut Bruinessen, Gerakan Tarbiyah mengambil bentuk pada tahun 1980-an, dan hadir sebagai gerakan mahasiswa pasca-peristiwa 1978. Gerakan ini bermula dari kelompok diskusi dan mental training yang digelar di masjid Salman Institut Teknologi Bandung (ITB). Mereka mengadakan kelompok-kelompok lingkaran studi (balâqah) secara rahasia yang disebut dengan usrah, sebuah terminologi yang terinspirasi dari gerakan al-Ikhwân al-Muslimûn di Mesir. Dalam lingkaran tersebut terdapat murabbî, seorang senior yang bertindak sebagai instruktur atau pembina, yang melatih dan mendisiplinkan yuniornya. Materi-materi pelatihannya kebanyakan berasal dari karyakarya tokoh-tokoh al-Ikhwân al-Muslimûn dan buku-buku karya Abû al-A'lâ al-Mawdûdî. ${ }^{37}$

Gagasan-gagasan al-Ikhwân al-Muslimûn memiliki pengaruh dominan dalam gerakan usrah melalui karya-karya itu. Selain itu, beberapa aktivisnya juga menjalin jaringan dengan organisasi pemuda Islam inetrnasional. Kebanyakan gerakan usrah bersifat apolitis dan menekankan pada perbaikan moral-personal anggotanya. Namun demikian, beberapa di antara mereka berafiliasi dengan beberapa tokoh NII/TII (Negara Islam Indonesia/Tentara Islam Indonesia), seperti Abu Bakar Baasyir yang meyakini pada pentingnya mendirikan negara Islam dan penerapan sharî́ah. ${ }^{38}$

34 Martin van Bruinessen, "Selayang Pandang Organisasi, Serikat, dan Gerakan Muslim di Indonesia", dalam Bruinessen (ed.), Conservative Turn, 62-63.

35 Ibid., 90-94.

36 Ibid., 78-79.

37 Martin van Bruinessen, "Geneologies of Islamic Radicalism in Post-Soeharto Indonesia", South East Asia Research, Vol. 10 No. 2 (2002), 117-154.

${ }^{38}$ Ibid. 
Sedangkan Hizbut Tahrir Indonesia (HTI) yang mengusung gagasan negara khilâfah muncul di Institut Pertanian Bogor (IPB) di awal 1980-an dan menjadi gerakan bawah tanah hingga 1998. Kelompok yang menolak demokrasi liberal ini memiliki pengikut yang cukup besar di kalangan muda terdidik, dan secara aktif terus melakukan rekrutmen anggota baru. Pada 2007 HTI melakukan show a force dengan melibatkan tidak kurang dari 100.000 orang. ${ }^{39}$

Gerakan Salafi di Indonesia ditrasmisikan oleh sekelompok sarjana yang telah kembali dari belajar di Saudi Arabia dan menyasar kalangan mahasiswa dan sejumlah madrasah. Bruinessen menyebut beberapa model Salafi, yaitu: Salafi murni yang apolitis dan direstui pemerintah Saudi, Salafi politis atau ḅarakî yang muncul akibat persentuhannya dengan gagasan al-Ikhwân al-Muslimûn, serta Salafî jỉhâdî yang memiliki jaringan dengan al-Qaeda. ${ }^{40}$ Menurut Bruinessen, Gerakan Salafi kurang bersentuhan dengan masyarakat hingga-paling tidakpada tahun 1999 ketika terjadi konflik antar-umat beragama di Maluku, ketika itu mereka memobilisasi diri untuk berjihad di sana. ${ }^{41}$

Kebanyakan gerakan-gerakan baru tersebut memiliki akar pada Dewan Dakwah Islamiyah Indonesia (DDII) yang berperan penting dalam proses transmisi gagasan dari Timur Tengah ke Indonesia. DDII memiliki hubungan erat dengan Arab Saudi dan Rabîtah al'Âlam al-Islâmî (Liga Muslim Dunia), dan banyak menyalurkan dana dari Timur Tengah untu kepentingan dakwah di Indonesia melalui pendirian rumah sakit, masjid, dan radio dakwah. DDII juga sering mengirim mahasiswa Indonesia untuk belajar ke Arab Saudi. Mahasiswa-mahasiswa itulah yang di kemudian hari menjadi agen penting dalam persebaran gagasan-gagasan dari Timir Tengah ke Indonesia setelah kembali dari studinya. Selain itu DDII juga turut membantu pendirian LIPIA (Lembaga Ilmu Pengetahuan Islam dan Arab) di Jakarta sebagai salah satu produsen kader salafi di Indonesia. ${ }^{42}$

Peran yang dimainkan DDII itu tidak lepas dari kedekatan Moh. Natsir-pendiri dan ketua DDII-dengan para pemimpin negara-

\footnotetext{
39 Bruinessen, "Selayang Pandang”, 75.

${ }^{40}$ Ibid., 94.

${ }^{41}$ Bruinessen, "Geneologies".

42 Muhammad Wildan, "Memetakan Islam Radikal: Studi Atas Suburnya Gerakan Radikal di Solo, Jawa Tengah," dalam Bruinessen (ed.), Conservative Turn, 274-277. Lihat juga Abdurrahman Wahid (ed.), Ilusi Negara Islam: Ekspansi Gerakan Islam Transnasional di Indonesia (Jakarta: The Wahid Institute, 2009), 78 dan 98.
} 
negara dan organisasi Islam di Timur Tengah. Dengan motif menahan gerak laju gerakan pembaruan Islam yang memiliki orientasi ke sekularisme, dan mengimbangi program pengiriman akademisi Muslim ke negara-negara Barat oleh Departemen Agama yang dipimpin Munawir Sadzali, Natsir pun mulai aktif mengirim anakanak muda Muslim untuk belajar Islam di Timur Tengah. ${ }^{43}$

Dengan demikian, sesungguhnya kelompok Islam radikal yang terinspirasi oleh gerakan-gerakan Islam di Timur Tengah telah ada sebelum era reformasi. Hal itu ditandai oleh tanggapan sengit beberapa tokoh atas gagasan pembaruan yang dilontarkan Nurcholish Madjid pada dekade 1970-an. Namun otoritarianisme Orde Baru membuat ruang gerak gerakan-gerakan tersebut terbatas sehingga mereka pun "tiarap" dan bergerak di bawah tanah. Kejatuhan Soeharto seakan menjadi pintu pembuka bagi gerakan-gerakan tersebut untuk tampil ke permukaan menunjukkan jati dirinya. Kenyataan ini melahirkan asumsi bahwa gerakan Islam moderatliberal menjadi superior ketika mereka didukung oleh kekuatan politik yang otoriter, dan menjadi inferior ketika mereka berada dalam lingkungan yang terbuka-demokratis. ${ }^{44}$

Secara lebih terperinci Machmudi melihat beberapa faktor yang membuat kemunculan gerakan Islam baru dan santri baru tersebut, yaitu: sikap represif pemerintah Orde Baru dan Kegagalan Politik Islam; pengaruh dari pendidikan agama dan keagamaan; dan pengaruh dinamika Islam internasional, khususnya revolusi Islam Iran di akhir dekade 1970-an. ${ }^{45}$

\section{Islam Transnasional versus Islam Nusantara}

Meski sama-sama memiliki inspirasi dari dan koneksi dengan Timur Tengah, kehadiran gerakan-gerakan Islam baru tersebut tak pelak mengusik gerakan-gerakan Islam mainstream (NU dan Muhammadiyah) yang telah lebih dulu mapan. Gaya berdakwah baru dengan model usrah yang berjejaring layaknya multi level, serta gagasangagasan baru yang beda dari apa yang selama ini ditawarkan gerakan Islam mainstream cukup memikat banyak kalangan Muslim.

Mahasiswa dan kelas menengah terdidik menjadi pihak yang paling banyak masuk dalam gerakan-gerakan baru tersebut. Hal yang wajar

\footnotetext{
43 Machmudi, "Islamising Indonesia", 29.

44 Ibdi., 23. Zainal Abidin Bagir, "Membaca Beragam Wajah Islam Indonesia," dalam Bruinessen (ed.), Conservative Turn, 11-23.

${ }^{45}$ Machmudi, "Islamising Indonesia", 23-30.
} 
mengingat konsentrasi dakwah yang mereka lakukan memang kampus-kampus mapan di perkotaan, terutama kampus negeri besar seperti Institut Pertanian Bogor (IPB), Institut Teknologi Bandung (ITB), Universitas Gadjah Mada (UGM) Yogyakarta, Universitas Indonesia (UI) Jakarta, Universitas Brawijaya (UB) Malang, Universitas Airlangga (Unair) Surabaya, dan beberapa kampus lainnya. Setelah mapan di kampus, gerakan-gerakan baru tersebut mulai melebarkan wilayah dakwahnya ke masyarakat umum di luar kampus.

Gerakan Islam mainstream yang mengalami persinggungan paling keras dengan gerakan baru tersebut tentu saja adalah Muhammadiyah, yang sejak mula memiliki basis massa kelas menengah perkotaan. Dalam catatan Ahmad Najib Burhani, di akhir 2005 muncul keluhan di kalangan Muhammadiyah tentang aksi ambil alih masjid yang dikelola Muhammadiyah oleh aktivis Tarbiyah. Contoh kasusnya adalah yang terjadi pada sebuah masjid Muhammadiyah di Sendang Ayu, Lampung. Atau juga masjid di Universitas Ahmad Dahlan (UAD) Yogyakarta dan masjid di Universitas Prof. Dr. Hamka Jakarta, yang diambil alih dengan mengganti pengurus takmir dan programprogram kerjanya.

Bukan hanya masjid, tuduhan aksi ambil alih tersebut melebar pada beberapa amal usaha milik Muhammadiyah, seperti sekolah, kampus, dan rumah sakit. Burhani mencontohkan kasus yang terjadi di Boyolali di mana sekolah dasar milik Muhammadiyah yang coba diambil pengelolaannya oleh aktivis PKS. Lebih dari itu, dugaan "penyerobotan" juga terjadi pada Sumber Daya Manusia (SDM) Muhammadiyah. Banyak kader dan pengurus Muhammadiyah yang mengalami loyalitas ganda karena mereka merangkap sebagai kader Tarbiyah dan PKS. Bahkan kader-kader rangkap keanggotaan tersebut ternyata lebih loyal kepada Tarbiyah daripada Muhammadiyah. Hal itu dibuktikan saat penentuan Idul Adha 2005 dimana banyak kaderpengurus Muhammadiyah yang menyelenggarakan salat 'Id pada Kamis 20 Juni, padahal Pengurus Pusat Muhammadiyah menetapkan Idul Adha jatuh pada Jumat 21 Juni. $^{46}$

Tuduhan adanya aksi ambil alih pertama kali dilontarkan Abdul Munir Mulkhan dalam artikelnya di Suara Mubammadiyah, edisi 2 Januari 2006, yang menceritakan sebuah masjid Muhammadiyah di

46 Ahmad Najib Burhani, "Islam Murni vs Islam Progresif di Muhammadiyah: Melihat Wajah Islam Reformis Indonesia", dalam Bruinessen (ed.), Conservative Turn, 175-176. 
Sendang Ayu, Lampung, berubah karakter setelah disusupi orangorang PKS. Artikel itu segera menyulut reaksi dari Ketua DPD Ikatan Mahasiswa Muhammadiyah (IMM) Yogyakarta, Farid Setiawan, yang menulis artikel tanggapan di Suara Mubammadiyah edisi 20 Februari dan 3 April 2006. Dalam kedua artikelnya Setiawan memaparkan betapa sudah begitu dalam dan luasnya infiltrasi kelompok Tarbiyah hingga telah meresap dalam lembaga-lembaga kaderisasi Muhammadiyah. Setiawan juga mendesak agar PP Muhammadiyah segera mengambil langkah-langkah tegas untuk mengamputasi virus-virus tersebut agar gerakan yang didirikan $\mathrm{KH}$ Ahmad Dahlan tersebut tidak cepat tutup usia. ${ }^{47}$

Muhammadiyah bergerak cepat dengan mengeluarkan Surat Keputusan No 149/Kep/I.0/B/2006 tanggal 1 Desember 2006. SK tersebut menginstruksikan kepada seluruh pengurus Muhammadiyah untuk melepaskan diri dari segala bentuk aktivitas politik demi menjaga kesetiaan dan komitmen pada Muhammadiyah, mengoptimalkan pelatihan kader dan menegakkan disiplin organisasi. Keputusan tersebut dikuatkan dalam keputusan Tanwir di Yogyakarta 26-29 April 2007 yang membahas strategi Muhammadiyah dalam menghadapi gerakan-gerakan Islam baru seperti PKS dan HTI, serta melahirkan kebijakan "disiplin organisasi". Hasil Tanwir itu pun dijabarkan lebih lanjut dalam keputusan PP Muhammdiyah No $101 / 2007$ yang melarang semua pengurus di segala tingkatan untuk merangkap jabatan di partai politik dan organisasi massa lainnya. ${ }^{48}$

Meski bereaksi dengan menerapkan "disiplin organisasi", beberapa kader Muhammadiyah juga mengajak melakukan introspeksi atas gerak jalan Muhammadiyah selama ini. Fajar Riza Ul Haq menilai saat ini Muhammadiyah berada di persimpangan jalan pembaruan Islam. Sebagai pioner gerakan pembaruan, Haq menilai saat ini peran-peran perubahan yang dilakukan Muhammadiyah menjadi semakin tidak bergairah. Cara pandang warga Muhammadiyah yang cenderung inward looking bahkan reaksioner saat berhadapan dengan tantangan kemanusiaan dianggapnya sebagai sebab dari meredupnya peran Muhammadiyah itu. Sebab lainnya menurut Haq adalah terjadinya krisis kepemimpinan, kemandegan kaderisasi di segala lini,

47 Abdurrahman Wahid, "Musuh dalam Selimut," dalam Wahid (ed.), Ilusi Negara, 23-25.

48 Burhani, "Islam Murni vs Islam Progresif”, dalam Bruinessen (ed.), Conservative Turn, 177-179. Lihat juga Wahid, "Musuh dalam Selimut" dalam Wahid (ed.), Ilusi Negara, 26-27. 
ketergantungan terhadap negara sebagai akibat pergeseran mentalitas pedagang menjadi mentalitas abdi negara. ${ }^{49}$

Bagi Azra, Muhammadiyah bukan sekali ini berhadapan dengan gerakan transnasional. Pada dasawarsa kedua abad ke 20 Muhammadiyah telah menghadapi tantangan Ahmadiyah yang memiliki doktrin kenabian Mirza Ghulam Ahmad dan kesatuan kepemimpinan umat Islam dalam bidang keagamaan. Pada dekade 1950-an Muhammadiyah pun berhadapan dengan Jamaah Tabligh yang memiliki dakwah proaktif door to door melalui program khurûj. Baru setelah itulah Muhammadiyah berhadapan dengan gerakan transnasional lain semacam Hizbut Tahrir. ${ }^{50}$

Bukan hanya Muhammadiyah yang merasa terusik, Nahdlatul Ulama (NU) yang notabene berbasis pedesaan juga mengalami hal serupa. Dengan mengutip laporan majalah yang dikelola anak-anak muda NU, Syir'ah, Burhani menceritakan bahwa masjid al-Bahri di Jatinegara, Jakarta Timur yang dirikan Guru Marzuki yang sudah diambil alih kelompok Islam baru dan pengurus baru tersebut melarang kegiatan kasidahan di masjid tersebut. ${ }^{51}$

Dalam merebut masjid-masjid yang dikelola NU, Wahid menulis, aktivis gerakan Islam baru tersebut awalnya memberikan layanan cleaning service gratis. Setelah mendapat simpati dari takmir, mereka pun mulai naik kelas dengan menjadi muadzin dan masuk ke struktur kepengurusan masjid (takmir). Setelah memiliki posisi yang kuat, mereka pun mulai menguasai kepengurusan masjid dan menentukan program-programnya. Dengan demikian secara perlahan-lahan masjid-masjid yang semula dikelola NU pun telah berpindah tangan ke gerakan-gerakan baru itu. Menghadapi itu, NU segera melakukan konsolidasi dan menyatakan menolak paham yang dianut gerakangerakan tersebut. NU juga mendesak pemerintah untuk segera memotong ideologi transnasional karena berbahaya bagi paham Aswaja (Ahl al-Sunnah wa al-Jamâ'ah) dan menuduh gerakan-gerakan baru itu dapat memecah belah bangsa. ${ }^{52}$

${ }^{49}$ Fajar Riza Ul Haq, "100 Tahun Muhammadiyah: Apa Kabar dan Mau Kemana?”, Maarif Vol. 4 No. 2 (Desember 2009), 8.

50 Azyumardi Azra, "Muhammadiyah: Tantangan Islam Transnasional", Maarif, Vol. 4, No. 2 (Desember 2009), 16-18.

51 Burhani, "Islam Murni vs 'Islam Progresif', dalam Bruinessen (ed.), Conservative Turn, 175-176.

52 Wahid, "Musuh dalam Selimut” dalam Wahid (ed.), Ilusi Negara, 28-31. 
Gerakan Islam transnasional juga disebut telah berhasil menyusup ke Majelis Ulama Indonesia (MUI) sehingga merubah wajah organisasi itu menjadi "moderat puritan". Perubahan itu menurut Nur Ichwan ditandai oleh tiga hal, yaitu: pertama, MUI menjadi lebih legalistik dengan berorientasi normatif pada isu halal-haram di bidang makanan, kosmetika, obat-obatan, perbankan, asuransi dan masalah ekonomi-keuangan lainnya; kedua, rekrutmen beberapa anggota baru yang lebih radikal. Pengurus MUI bukan lagi dari kalangan organisasi modernis dan tradisionalis, tetapi juga memasukkan unsur gerakan puritan dan radikal; ketiga, MUI ikut campur tangan pada urusan publik dengan melakukan proses hukum dan politik di parlemen atau dengan demonstrasi. Tidak menjadi lembaga penjaga moral melalui fatwa, tausiyah, atau pernyataan publik lainnya; dan keempat, MUI menjadi semakin eksklusif dengan hanya melindungi kepentingan umat Islam ketimbang berupaya merangkul kepentingan nasional. ${ }^{53}$

Lebih lanjut Ichwan menyatakan, proses rekrutmen pihak-pihak yang dianggap radikal dan islamis ke dalam MUI terjadi sejak Musyawarah Nasional (Munas) tahun 2000. Ichwan menyebut beberapa tokoh Islam radikal yang masuk kepengurusan MUI saat itu, seperti Adian Husaini, Cholil Ridwan, dan Amin Djamaluddin. Pada Munas 2005 MUI juga memasukkan beberapa tokoh HTI dan Forum Umat Islam (FUI) dalam kepengurusannya. Bukan hanya di pusat, hal serupa juga terjadi di daerah-daerah. Meski demikian, Ichwan melihat, MUI tetap mencoba melakukan upaya mediasi berbagai aliran Islam di Indonesia dengan memasukkan beberapa tokoh yang dianggap liberal dalam kepengurusannya, seperti Masdar Farid Mas'udi dan Siti Musdah Mulia. ${ }^{54}$ Ichwan memberikan beberapa contoh pengaruh gerakan-gerakan baru tersebut sehingga bisa merubah wajah MUI, di antaranya adalah dukungan terhadap RUU Anti Pornografi dan Pornoaksi, RUU Sistem Pendidikan Nasional, dan fatwa sesat terhadap sekularisme, pluralisme dan liberalisme (Sipilis). ${ }^{55}$

Azra melihat tantangan gerakan Islam transnasional terhadap gerakan Islam mainstream disebabkan oleh dua faktor: pertama, kehadiran dan aktivisme gerakan transnasionalisme dalam segi-segi tertentu menunjukkan masih terdapat ruang-ruang kosong yang

53 Moch Nur Ichwan, "Menuju Islam Moderat Puritan: Majelis Ulama Indonesia dan Politik Ortodoksi Keagamaan," dalam Bruinessen (ed.), Conservative Turn, 105106.

${ }^{54}$ Ibid., 107-108.

${ }^{55}$ Ibid., 103. 
belum berhasil diisi Muhammadiyah dan gerakan arus utama lainnya seperti NU; ${ }^{56}$ dan kedua, gerakan Islam arus utama tampak terlambat mengantisipasi perubahan dan dinamika yang terjadi di kalangan umat, khususnya dalam kaitan dengan Islam internasional. Keterlambatan itu boleh jadi karena mereka lebih banyak terfokus pada kegiatan-kegiatan rutin, atau bahkan juga pada isu-isu politik domestik, sehingga tidak atau kurang waspada terhadap penetrasi pemikiran dan gerakan transnasional. ${ }^{57}$

\section{Pertarungan Wacana}

Dalam suasana gesekan seperti itulah wacana Islam Nusantara kemudian muncul ke permukaan. Dengan menggunakan kata "Nusantara" untuk menyifati kata "Islam", pendukung wacana tersebut tampak sedang mengidentifikasikan dirinya sebagai gerakan Islam yang indigenouse, mengingat Nusantara merupakan sebutan lain dari kata Indonesia, atau merujuk pada gugusan pulau-pulau yang terletak di Malaysia, Singapura, Brunei Darussalam, Filipina Selatan, Thailand Selatan, dan sebagian besar berada di wilayah Negara Kesatuan Republik Indonesia (NKRI). ${ }^{58}$

Identifikasi seperti itu penting untuk menunjukkan superioritas gerakan-gerakan Islam mainstream yang lebih dahulu ada terhadap gerakan-gerakan baru tersebut. Dengan itu diharapkan masyarakat memandang gerakan-gerakan baru tersebut sebagai "asing" dan "aneh", kemudian melahirkan respons negatif terhadap gerakangerakan baru tersebut, dan akhirnya pengaruh gerakan-gerakan Islam baru itu di tengah-tengah publik Islam Indonesia menjadi semakin pudar. Lebih dari itu, seperti yang dinyatakan Said Aqil Siroj di atas, gerakan-gerakan Islam baru itu bisa dilarang keberadaannya di wilayah NKRI.

Untuk meneguhkan kesan tersebut, tokoh-tokoh gerakan Islam mainstream menggunakan terminologi "gerakan Islam Transnasional" untuk menyebut gerakan-gerakan Islam baru itu, dan melabelinya dengan berbagai sifat yang peyoratif seperti keras, kaku, radikal, ekstrem, literal, berpandangan hitam-putih, suka melakukan kekerasan dan sifat-sifat lain yang berbeda dan bertentangan dengan karakter

\footnotetext{
56 Azra, "Muhammadiyah", 18.

${ }^{57}$ Ibid., 19.

${ }^{58}$ Yahya Cholil Staquf, "Islam Merangkul Nusantara”, dalam Sahal dan Aziz (eds.), Islam Nusantara, 191.
} 
masyarakat Nusantara yang dikenal sebagai ramah, terbuka, dan antikekerasan.

Padahal jika dilihat secara cermat, tidak semua sifat peyoratif itu melekat secara inhern dalam gerakan-gerakan Islam transnasional itu. Bruinessen sendiri membedakan tiga model gerakan Salafi: Salafi murni yang apolitis, Salafi Haraki yang politis, dan Salafi Jihadi. Bruinessen menyebut dari semua gerakan salafi di Indonesia, hanya Jama'ah Islamiyah dan Jama'ah Ansharut Tauhid yang tergolong Salafi Jihadi. Sedangkan gerakan salafi lainnya semacam Wahdah Islamiyah, Majelis Mujahidin Indonesia (MMI), atau pun Forum Komunikasi Ahlussunnah Wal Jama'ah (FKAWJ) pimpinan Ja'far Umar Thalib masuk dalam kategori Salafi apolitis atau Salafi politis. Meski di masa lalu FKAWJ sempat bermetamorfosis menjadi gerakan paramiliter dalam bentuk Laskar Jihad. ${ }^{59}$

Terminologi "Islam Transnasional" untuk menyebut gerakangerakan baru yang beragam tersebut tentu saja layak dipertanyakan kembali. Jika merujuk pada makna gerakan transnasional sebagai gerakan yang bersifat melintasi batas-batas nasionalisme Indonesia, maka hampir seluruh gerakan-gerakan Islam yang ada di Indonesia saat ini mengambil inspirasi gagasan, teologi, ideologi dan pola perjuangan dari gerakan-gerakan lain di luar wilayah Indonesia; Muhammadiyah yang didirikan oleh $\mathrm{KH}$ Ahmad Dahlan disebut terinspirasi oleh gagasan reformisme-modernisme Muhammad 'Abduh; sementara Nahdlatul Ulama (NU) yang disebut mengikuti sufisme Imâm al-Ghazâlî, teologi Aswaja Ash'ârîyah dan Mâturîdîyah, serta fiqh Shâfîîyah jelas-jelas mengambil inspirasi gagasan-teologi yang transnasional.

Jaringan ulama Nusantara dengan Timur Tengah yang terbangun sejak abad ke 17 M sesungguhnya semakin meneguhkan karakter trans-nasionalitas gerakan-gerakan Islam yang lebih dulu ada di Indonesia, terutama NU. ${ }^{60}$ Ulama yang menjadi mata rantai tersebut hadir dengan beragam pemikiran. Tidak semuanya bersifat terbuka, toleran, dan bisa menerima paham-adat lokal yang ada di masyarakat. Ada di antara mereka yang tegas, keras dan berorientasi pada aspek legal-formal agama, sifat-sifat yang sering diatribusikan kepada

\footnotetext{
${ }^{59}$ Bruinessen, "Selayang Pandang," dalam Bruinessen (ed.), Conservative Turn, 94-95.

60 Tentang jaringan ulama Nusantara dengan Timur Tengah abad 17-18 tersebut lihat Azyumardi Azra, Jaringan Ulama Timur Tengah dan Kepulauan Nusantara Abad XVII \& XVIII (Jakarta: Kencana, 2013).
} 
gerakan-gerakan Islam baru. Nuruddin al-Raniri umpamanya secara tegas menolak tasawuf wujûdîyah yang sudah tersebar luas di tengah masyarakat Aceh sebelum ia datang. Al-Raniri menyebut pengikut paham tersebut sebagai sesat dan politeis (syirik). Bahkan ia memanfaatkan pengaruh keagamaan dan politiknya untuk menghukum mati para pengikut wijûdîyah. ${ }^{61}$

Sikap tegas al-Raniri terhadap paham wujudîyah itu disebut oleh Iik Mansurnoor sebagai gerakan radikal Islam awal di Asia Tenggara. ${ }^{62} \mathrm{Di}$ kemudian hari, di akhir abad ke 18 dan awal abad ke 19, kelompok reformis melakukan aksi pemberantasan terhadap praktik syirik, sinkretisme dan bid'ah dalam agama.

Menurut Mansurnoor, kemunculan gerakan radikal di Nusantara bukan hanya disebabkan oleh persebaran paham Wahabisme dan perubahan sosio-politik-ekonomi yang cepat akibat semakin menguatnya kekuatan kolonial dan dominasi ekonomi Barat, namun juga akibat dari sirkulasi literatur Islam genre baru di kalangan sarjana Islam di Nusantara. Dalam hal ini peran yang ditampilkan oleh sarjana-sarjana Muslim asal Nusantara hasil didikan Hijaz tidak bisa disangkal. Mansurnoor menyebut dua sarjana terkemuka 'Abd Șamad al-Falimbangî dan Dawd b. 'Abd Allah al-Fâtanî sebagai sarjanasarjana genre baru tersebut. ${ }^{63}$

Wajah Islam Nusantara yang tegas seperti itu juga terlihat pada Gerakan Padri di Sumatera Barat awal abad ke 19. Gerakan yang digawangi trio haji: Haji Miskin, Haji Abdurrahman, dan Haji Muhammad Arif tersebut dinilai Wahid dan kawan-kawan sebagai gerakan yang telah terinfiltrasi paham Wahabi dengan aksi pembaruannya yang keras dan non-toleran. Wahid mencatat gerakan Padri memvonis sesat Tarekat Shațariyah dan gerakan tasawuf lainnya di Minangkabau, dan mengafirkan pihak lain yang tidak sepaham dengan mereka. ${ }^{64}$

Demikian juga yang terjadi dengan Dewan Dakwah Islamiyah Indonesia (DDII) yang sering dinilai sebagai pihak yang bertanggungjawab dalam menanamkan benih-benih gerakan transnasional di Indonesia. Meski dinilai keras dan memiliki jaringan

${ }^{61}$ Azra, Jaringan Ulama, 227.

62 Iik Mansurnoor, "Revivalism and Fundamentalism in Southeast Asian Islam: A Pattern or an Anomaly?", New Zealand Journal of Asian Studies, Vol. 11, No. 1 Juni 2009), 234.

${ }^{63}$ Mansurnoor, "Revivalism", 234.

${ }^{64}$ Wahid (ed.), Ilusi Negara, 93. 
dengan gerakan Salafi-Wahabi Timur Tengah, Pemerintah Republik Indonesia mengakui tokoh-tokoh Padri dan DDII sebagai bagian integral dalam pembentukan republik. Tercatat tokoh Padri Imam Bonjol, pendiri DDII Mohammad Natsir, dan tokoh Masyumi Syafruddin Prawiranegara secara resmi diakui sebagai pahlawan nasional. Pun demikian dengan al-Raniri yang tetap diakui sebagai bagian dari ulama' Nusantara.

Yang ingin ditekankan di sini adalah bahwa wajah Islam Nusantara sesungguhnya tidak monolitik sebagaimana yang digambarkan penyokong wacana Islam Nusantara. Posisi kepulauan Nusantara yang strategis dan telah terintegrasi dengan jaringan perdagangan internasional sejak ratusan tahun lalu memastikan sebuah wajah peradaban yang bercorak warna-warni dan beragam. Menganggap Islam di Nusantara hanya satu warna merupakan sikap yang reduktif.

Proses arabisasi seperti yang dikhawatirkan beberapa kalangan terkait dengan kemunculan gerakan-gerakan Islam transnasional juga merupakan sesuatu yang berlebihan, karena sesungguhnya proses itu telah terbentuk seiring dengan islamisasi Nusantara beberapa abad lalu. Seperti yang terjadi di bidang bahasa, islamisasi turut memasukkan unsur kosakata Arab dalam perbendaharaan bahasabahasa di Nusantara, yang hingga tetap dipakai sebagai bagian dari khazanah kebahasaan Melayu-Indonesia. Sebagian besar kosakata tersebut terkait bidang keagamaan, dan sebagian lainnya menyangkut bidang sosial, budaya, dan politik.

Azra menulis, dalam Kamus al-Hamidi karya Abdul Hamid Ahmad dicatat sekitar 2000 kosakata Arab dalam Bahasa Melayu-Indonesia. Sedangkan Muhammad Said dalam Guguskata Arab Melayu mendaftar sekitar 1.725 kosakata, Kamus Istilah Islamiyah karya Muhammad Sanusi ibn Haji Mahmood mencatat sekitar 2000 kosakata. Sementara James Howison mencatat hanya sekitar 150 kosakata, Shellabear mendaftar 385 kata, Swettenham hanya mencatat sekitar 219 kata, Winstedt dan Linggi dalam Kitab Loghat Melayu mendaftar sekitar 1.001 kosakata Arab yang diadopsi dalam Bahasa Melayu-Indonesia. Istilah "daulat", "sultan", "malik", "khalifah", "baiat", "tadbir", "harb", "jihad", "aman", "amar", "wathan", "majlis", "musyawarah", "umat”, "siasat”, "adil", "zalim", "syarikat", "amanah", "hukum", dan "qanun" 
merupakan contoh-contoh adopsi kosakata Arab dalam perbendaharaan Bahasa Melayu-Indonesia. ${ }^{65}$

Lebih dari itu, arabisasi bahasa dan sastra di Nusantara juga terjadi pada penggunaan aksara Arab menggantikan aksara Sansekerta yang bersumber dari India. Lombard mencatat, menjelang tahun 1880 aksara Arab masih digunakan luas untuk menuliskan Bahasa Melayu dan beberapa bahasa setempat (seperti bahasa Aceh, Minangkabau, atau Jawa). Namun penggunaan aksara Arab-Melayu itu pun mulai luntur digantikan aksara Latin di era kolonialisme Barat pada dasawarsa pertama abad ke $20 .^{66}$

Bukan hanya di bidang bahasa dan sastra, kehadiran Islam di Nusantara juga telah memberikan perubahan fundamental di bidang sosial budaya masyarakat Nusantara. Anthony Reid menjelaskan, keberislaman penduduk Nusantara telah merubah cara dan pola hidup mereka, sehingga seolah-olah mereka telah melakukan perubahan etnis. Ini untuk menggambarkan betapa fundamental perubahan yang terjadi sebagai akibat dari proses islamisasi. ${ }^{67}$ Reid memberikan contoh, sebelum kedatangan Islam para istri di Jawa dan Bali diharuskan membakar diri mereka dalam api pembakaran jenazah suaminya. Sementara di Filipina, Sulawesi, Kalimantan, Nias, Kamboja dan Burma para budak sering dibunuh untuk menemani tuan-tuan mereka di dunia sana. ${ }^{68}$

Lebih jauh Reid mencatat, sebagai konsekuensi dari proses konversi ke Islam, masyarakat harus meninggalkan kebiasaan makan daging babi. Ini merupakan proses yang sulit mengingat babi merupakan sumber daging utama dan unsur utama dalam ritual upacara-upacara sebelum Islam. Islam juga menyebabkan kaum lakilaki harus melakukan sunat (khitân). Begitu kuatnya perubahan itu sehingga di dua hal ini (sunat dan tidak makan babi) menjadi identitas utama keberislaman seseorang. Reid menulis: "Tidak pernah ada orang Lutao (Ternate-Mindanao) yang tidak disunat, atau yang makan

65 Azyumardi Azra, Renaisans Islam Asia Tenggara: Sejarah Wacana dan Kekuasaan (Bandung: Rosda, 2000), 76-77. Denys Lombard menyebut sekitar 3000 kosakata Arab yang diserap dalam perbendaharaan Melayu-Indonesia. Lihat Denys Lombard, Nusa Jawa Silang Budaya, Bagian I, terj. Winarsih PA, Rahayu SH, dan Nini HY (Jakarta: Gramedia, 2008), 163.

${ }^{66}$ Lombard, Nusa Jawa, 163-166.

67 Anthony Reid, Asia Tenggara Dalam Kurun Niaga 1450-1680 Jilid 2 (Jakarta: Yayasan Pustaka Obor Indonesia, 2015), 166.

${ }^{68}$ Ibid., 164. 
babi-dan inilah yang menjadi ciri keislaman mereka... karena mereka tidak mengetahui tentang al-Qur'ân". Selain perubahan itu, Islam juga memberikan efek perubahan sosial yang luar biasa pada masyarakat Nusantara di bidang makanan, pakaian, dan gaya rambut. ${ }^{69}$

Karena itulah, Reid menolak anggapan sebagian penulis yang menyebutkan bahwa proses islamisasi Nusantara-terutama di Jawa-tidak memberikan efek yang fundamental dan hanya menyentuh aspek kulit luar saja. Menurutnya, Islam tidak hanya menambah kalimat syahadat, doa, dan upacara-upacara lain sebagai pengganti upacara lama yang telah berlaku di masyarakat. Lebih dari itu, Islam telah memberikan perubahan besar pada masyarakat mengingat agama ini merupakan agama profetik yang menawarkan jalan eksklusif ke arah penyelamatan, dan menuntut pemeluknya untuk menampakkan ciri-ciri eksternal tertentu dalam kehidupannya sebagai umat. Islam tidak hanya menuntut ketaatan pasif para pemeluknya, namun juga mengharuskan mereka untuk meninggalkan kebiasaan jahiliah dari masa sebelumnya sebagai ciri utama peralihan agama. $^{70}$

\section{Penutup}

Yang terjadi dalam wacana Islam Nusantara vis a vis Islam transnasional sesungguhnya merupakan gesekan antara gerakangerakan Islam mainstream (santri lama) dengan gerakan Islam baru (santri baru) dalam memperebutkan pengaruhnya di tengah publik Muslim di Indonesia. Kehadiran gerakan Islam baru tersebut yang mendapatkan sambutan hangat dari masyarakat cukup memberikan goyangan pada posisi gerakan Islam mainstream yang selama ini menikmati kenyamanan status quo-nya. Kekhawatiran pada perkembangan gerakan-gerakan Islam baru yang kian menarik minat masyarakat membuat gerakan-gerakan Islam mainstream tergerak untuk mempertahankan statusnya dengan menggunakan strategi permainan bahasa dan wacana yang diharapkan dapat membendung arus perkembangan itu. Penggunaan wacana "Islam Nusantara" dijadikan identifikasi bagi gerakan-gerakan mainstream karena secara inhern mengandungi pesan indigenouse.

Namun penggunaan istilah itu sendiri terkesan ambigu dan arbriter mengingat gerakan-gerakan mainstream itu sendiri sesungguhnya bagian tak terpisahkan dari jaringan Islam transnasional yang

\footnotetext{
${ }^{69}$ Ibid., 166.

70 Ibid., 165.
} 
terbangun sejak abad ke 17. Nahdlatul Ulama (NU) sebagai gerakan penggagas wacana tersebut sesungguhnya merupakan bagian tak terpisahkan dari gerakan Islam transnasional itu sendiri. Dengan klaim sebagai bagian dari mazhab Ahl al-Sunnah wa al-Jamâ'ah yang berpedoman pada teologi Ash'ârîyah dan Mâturîdîyah, empat mazhab (Shâfíî, Malikî, Hanbalî, dan Ḥanafî) di bidang fiqh, serta tasawuf Sunnî ala al-Ghazâlî, sesungguhnya NU secara langsung telah mengaitkan dirinya dengan jaringan Islam lintas negara. Pun demikian dengan Muhammadiyah yang mengambil insprirasi gerakannya dari gerakan modernisme Islam Muhammad 'Abduh serta pemurnian Islam ala Muḥammad b. 'Abd al-Wahhâb juga terikat secara langsung sebagai bagian dari jaringan Islam lintas negara.

Pendefinisian Islam Nusantara sebagai gerakan Islam yang mengadopsi nilai-nilai ke-Nusantara-an yang damai, sejuk dan cenderung mencari jalan tengah, justru dengan menyerang kelompokkelompok lain dari gerakan Islam baru malah tidak mencerminkan wajah Nusantara sesungguhnya, melainkan cenderung reduktif karena melihat dan menginginkan wajah islam di Nusantara secara monolitik. Dari bahasan di atas menjadi jelas bahwa wajah Islam di Nusanatara sejak awal mula memiliki tampilan yang beragam, dari yang halus hingga yang keras telah menjadi bagian dari Islam di Nusantara itu sendiri. Meski menyatakan bahwa Islam di Nusantara itu berwajah sejuk, namun sesungguhnya - disadari atau tidak-bangsa Indonesia telah mengakui model Islam yang "keras" juga menjadi bagian tak terpisahkan dari peradaban Islam di Nusantara itu sendiri.

\section{Daftar Rujukan}

Azra, Azyumardi. "Jaringan Ulama Nusantara", dalam Akhmad Sahal dan Munawir Aziz (eds.), Islam Nusantara: Dari Ushul Fiqh hingga Paham Kebangsaan. Bandung: Mizan, 2015.

----. "Muhammadiyah: Tantangan Islam Transnasional", Maarif, Vol. 4, No. 2, Desember 2009.

-----. Jaringan Ulama Timur Tengah dan Kepulauan Nusantara Abad XVII \& XVIII. Jakarta: Kencana, 2013.

-----. Renaisans Islam Asia Tenggara: Sejarah Wacana dan Kekuasaan. Bandung: Rosda, 2000.

Bagir, Zainal Abidin. "Membaca Beragam Wajah Islam Indonesia," dalam Bruinessen (ed.), Conservative Turn, 11-23.

Bilal Ramadhan, "Din: 'Watak Islam di Indonesia Beda dengan di Timur Tengah'," dalam m.republika.co.id/berita/dunia- 
islam/islam-nusantara/15/11/05 /nxbsaz330-din-watak-islam-diindonesia-beda-dengan-di-timur-tengah (diakses 25 Februari 2016).

Bruinessen, Martin van. "Geneologies of Islamic Radicalism in Post-

Soeharto Indonesia", South East Asia Research, Vol. 10 No. 2 (2002), 117-154.

----. "Perkembangan Kontemporer Islam Indonesia dan 'Conservative Turn' Awal Abad Ke-21', dalam Martin van Bruinessen (ed.), Conservative Turn: Islam Indonesia dalam Ancaman Fundamentalisme. Bandung: Mizan, 2014.

-----. "Selayang Pandang Organisasi, Serikat, dan Gerakan Muslim di Indonesia", dalam dalam Martin van Bruinessen (ed.), Conservative Turn: Islam Indonesia dalam Ancaman Fundamentalisme. Bandung: Mizan, 2014.

Burhani, Ahmad Najib. "Islam Murni vs Islam Progresif di Muhammadiyah: Melihat Wajah Islam Reformis Indonesia", dalam dalam Martin van Bruinessen (ed.), Conservative Turn: Islam Indonesia dalam Ancaman Fundamentalisme. Bandung: Mizan, 2014.

Fatoni, Muhammad Sulthon. "NU dan Islam Nusantara," dalam

Akhmad Sahal dan Munawir Aziz (eds.), Islam Nusantara: Dari Ushul Fiqh hingga Paham Kebangsaan. Bandung: Mizan, 2015.

Ghazali, Abdul Moqsith. "Metodologi Islam Nusantara", dalam Akhmad Sahal dan Munawir Aziz (eds.), Islam Nusantara: Dari Ushul Figh hingga Paham Kebangsaan. Bandung: Mizan, 2015.

Haq, Fajar Riza Ul. "100 Tahun Muhammadiyah: Apa Kabar dan Mau Kemana?”, Maarif Vol. 4 No. 2, Desember 2009.

Hilmy, Masdar. "Akar-akar Transnasionalisme Islam Hizbut Tahrir Indonesia (HTI)," dalam Islamica: Jumal Studi Keislaman, Vol. 6, No. 1, September 2011.

Ichwan, Moch Nur. "Menuju Islam Moderat Puritan: Majelis Ulama Indonesia dan Politik Ortodoksi Keagamaan," dalam Martin van Bruinessen (ed.), Conservative Turn: Islam Indonesia dalam Ancaman Fundamentalisme. Bandung: Mizan, 2014.

Jurdi, Syarifuddin. "Pertautan Gerakan Wahdah Islamiyah dan Gerakan Transnasional," dalam al-Fikr: Jurnal Pemikiran Islam, Vol. 16, No. 3 (2012.

Lombard, Denys. Nusa Jawa Silang Budaya, Bagian I, terj. Winarsih PA, Rahayu SH, dan Nini HY. Jakarta: Gramedia, 2008. 
Machmudi, Yon. "Islamising Indonesia: The Rise of Jemaah Tarbiyah and the Prosperious Justice Party (PKS)". Disertasi--Australian National University, 2006.

Mansurnoor, Iik. "Revivalism and Fundamentalism in Southeast Asian Islam: A Pattern or an Anomaly?", New Zealand Journal of Asian Studies, Vol. 11, No. 1, Juni 2009.

Muhajir, Afifuddin. "Meneguhkan Islam Nusantara untuk Peradaban Indonesia dan Dunia", dalam Akhmad Sahal dan Munawir Aziz (eds.), Islam Nusantara: Dari Ushul Fiqh hingga Paham Kebangsaan. Bandung: Mizan, 2015.

Muhammad, Bilal. "Islam Indonesia Beda dengan Islam Timur Tengah," dalam http://www.kiblat.net/2015/03/19/azyumardiazra-islam-indonesia-beda-dengan-islam-arab/ diakses 25 Februari 2016.

Reid, Anthony. Asia Tenggara Dalam Kurun Niaga 1450-1680 Jilid 2. Jakarta: Yayasan Pustaka Obor Indonesia, 2015.

Rifai, Bahtiar. "Said Aqil Siradj: 'Islam Indonesia bukan Islam Arab,," dalam m.detik.com/news/wawancara/2978479/said-aqil-siradjislam-indonesia-bukan-islam-arab (diakses 25 Februari 2016.

Siroj, Said Aqil. "Rekonstruksi Aswaja Sebagai Etika Sosial," dalam Akhmad Sahal dan Munawir Aziz (eds.), Islam Nusantara: Dari Ushul Figh hingga Paham Kebangsaan. Bandung: Mizan, 2015.

Staquf, Yahya Cholil. "Islam Merangkul Nusantara", dalam Akhmad Sahal dan Munawir Aziz (eds.), Islam Nusantara: Dari Ushul Fiqh bingga Paham Kebangsaan. Bandung: Mizan, 2015.

Wahid, Abdurrahman (ed.). Ilusi Negara Islam: Ekspansi Gerakan Islam Transnasional di Indonesia. Jakarta: The Wahid Institute, 2009.

----. "Musuh dalam Selimut," dalam Wahid, Abdurrahman (ed.). Ilusi Negara Islam: Ekspansi Gerakan Islam Transnasional di Indonesia. Jakarta: The Wahid Institute, 2009.

Wildan, Muhammad. "Memetakan Islam Radikal: Studi Atas Suburnya Gerakan Radikal di Solo, Jawa Tengah," dalam Bruinessen (ed.), Conservative Turn. 